\title{
A Case of Schwannoma of the Tongue Base
}

\author{
Hyeong Joo Lee ${ }^{1}$, Seong Jun Won ${ }^{1}$, Jin Pyeong Kim¹, and Seung Hoon Woo ${ }^{1,2}$ \\ ${ }^{1}$ Department of Otorhinolaryngology, ${ }^{2}$ Institute of Health Sciences, College of Medicine, Gyeongsang National University, Jinju, Korea
}

\section{설기저부에 발생한 신경초종 1 예}

이형주 ${ }^{1} \cdot$ 원성준 $^{1} \cdot$ 김진평 $\cdot$ 우승훈 ${ }^{1,2}$

경상대학교 의과대학 이비인후과학교실, ${ }^{1}$ 건강과학원 ${ }^{2}$

\author{
Received February 24, 2015 \\ Revised March 26, 2015 \\ Accepted March 30, 2015 \\ Address for correspondence \\ Seung Hoon Woo, MD \\ Department of Otorhinolaryngology, \\ College of Medicine, \\ Gyeongsang National University, \\ 79 Gangnam-ro, Jinju 52727, Korea \\ Tel $+82-55-750-8173$ \\ Fax +82-55-759-0613 \\ E-mail lesaby@hanmail.net
}

Schwannomas are benign peripheral nerve sheath tumors. It is found rarely in the oral cavity but most commonly in the tongue followed by the palate, floor of mouth, buccal mucosa, and mandible. Because schwannoma of the base of tongue is exceedingly rare, it is often not immediately included in the differential diagnosis, causing delay in identification and treatment. We report here, with a review of the literature, a case of schwannoma of the base of tongue, which was misdiagnosed as a lingual thyroid. A 28 -year-old man presented with a base of tongue mass, which was first detected a month ago. The preoperative diagnosis was lingual thyroid on the basis of the physical findings and computerized tomographic findings. The permanent pathologic report of the mass was schwannoma. Postoperatively, the patient showed no problem with tongue function and wound healing.

Korean J Otorhinolaryngol-Head Neck Surg 2016;59(3):229-32

Key Words Lingual thyroid $\cdot$ Schwannoma $\cdot$ Tongue base $\cdot$ Transoral.

\section{서 론}

신경초종(schwannoma)은 신경초 세포(schwann cell)에 서 기원하는 양성 종양이다. ${ }^{1)}$ 시신경과 후각신경을 제외한 모 든 뇌신경, 척추신경 및 말초신경 등 신경초로 덮여 있는 어 떤 신경에서든 발생할 수 있다. 전체 신경초종의 약 25 45\% 가 두경부에서 발생하며 그중 $1 \%$ 가 구강에서 발생하는 것으 로 알려져 있다. ${ }^{2)}$ 구강 내에서는 혀가 가장 흔한 호발 부위이 고 그 다음으로는 협부 점막, 경구개, 구강저, 구순 순이다. ${ }^{3-5)}$ 이처럼 신경초종은 구강 내에서 발생하는 경우가 매우 드물 기 때문에 구강내 종양의 감별진단의 우선순위에서 제외되 는 경우가 많아 진단 및 치료가 늦어질 수 있다. 저자들은 수 술 전 설갑상선(lingual thyroid)을 의심하여 수술을 계획하 였으나, 수술 중 동결절편검사 및 영구조직검사에서 신경초 종으로 확진된 설 기저부에서 발생한 신경초종 1 예를 보고하 고자 한다.

\section{증 겨}

28세 남자 환자가 한 달 전부터 발생한 인후두 불편감을 주 소로 본원 이비인후과 외래에 방문하였다. 인후두 불편감 및 이물감을 호소하였고 연하곤란, 연하통, 구음 장애, 수면 무호 흡 등의 증상은 없었다. 과거력상 외상이나 다른 질환은 없었 다. 신체 검진에서 설 기저부 정중선의 설맹공(foramen cecum) 에 $4 \times 4 \mathrm{~cm}$ 크기의 불규칙한 표면을 가진 단단하고 고정된 무통성의 종물이 관찰되었다(Fig. 1). 경부 조영 computed tomography(CT)상 소엽(lobulate)을 이루는 조영 증강이 되 는 종물이 설 기저부에서 후두덮개(epiglottis)까지 근접해 있 는 소견을 관찰할 수 있었다(Fig. 2). 갑상선기능검사상 free $\mathrm{T} 4$ 가 $1.88 \mathrm{ng} / \mathrm{dL}$ 로 경미하게 상승된 소견을 보였다. 구강으 로 돌출된 종물이기에 조직검사를 시도하였다. 그러나 환자 가 구역반사가 너무 심하였고, 종물에 대한 간단한 접촉만으 로도 출혈이 나타났다. 따라서 조직검사 시 출혈로 인한 흡인 (aspiration)의 위험을 고려하여 전신 마취하에 수술을 시행 


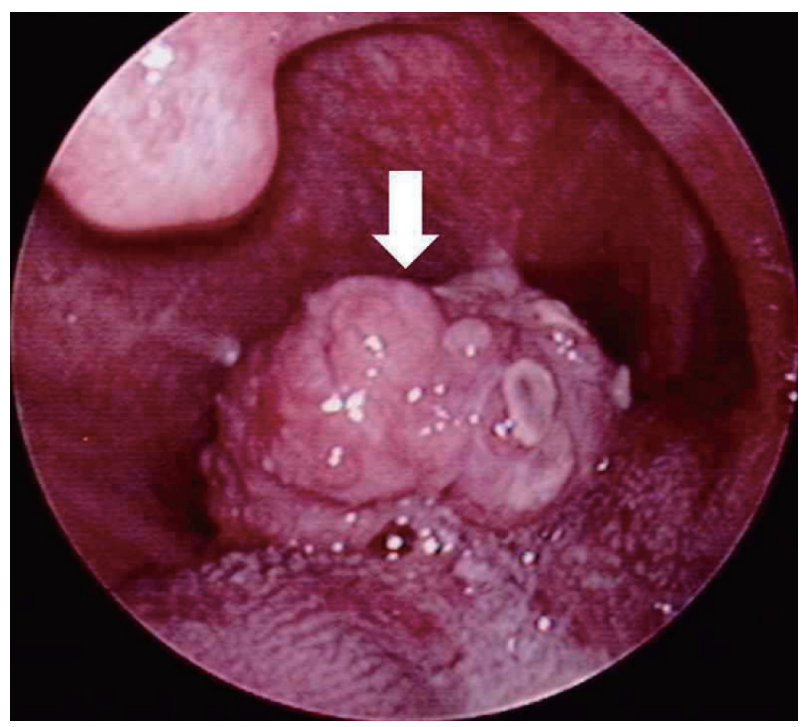

Fig. 1. Preoperative gross photo. A large protruding mass is found at the tongue base (white arrow).
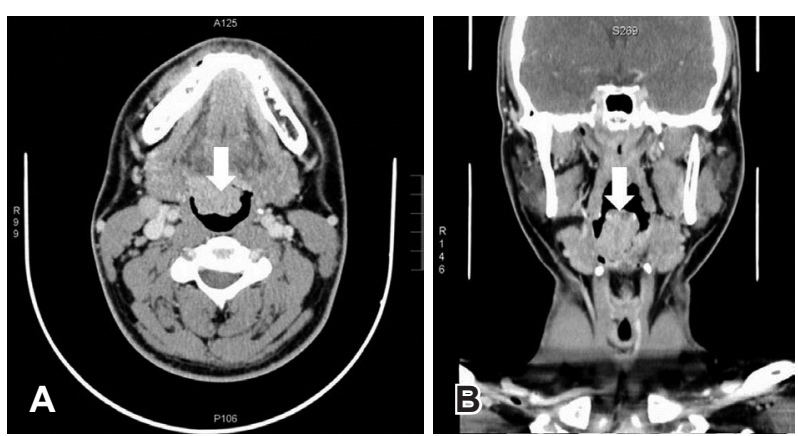

Fig. 2. Preoperative CT scan. Contrast-enhanced computed tomography axial $(A) \&$ coronal $(B)$ scan shows a well enhanced mass (white arrow).

하여 안전하게 제거하는 동시에 동결절편 검사를 계획하였 다. 다른 여러 감별 질환 중에서 종물이 설 기저부 정중선의 설맹공(foramen cecum)에 존재하는 원형의 종물이기에 설 갑 상선(lingual thyroid)으로 잠정진단하였다. 따라서 설 갑상선 에 대한 수술적 치료로서 경구강 접근법(transoral approach) 을 통한 종물의 완전 절제를 계획하였다.

수술 시 종물은 진성 피막에 의해 둘러싸여져 있었고 피막 내측을 따라 비교적 쉽게 박리가 되어 설 기저부에서 완전 제 거가 가능하였다. 수술 중 혈관손상이나 신경의 노출은 없었 다. 절제된 종물은 직경 $4.0 \times 2.8 \mathrm{~cm}$ 크기로 여러 개의 엽(lobule)을 이루며 표면은 불규칙한 모양이었으며, 내부는 균질한 절단면을 보였다. 수술 중 시행한 동결절편검사(frozen biopsy) 상 균질한 고형종물(homogenous solid tumor) 양상으로 신경 초종(schwannoma) 의심 소견을 보고받았다. 잔여 조직 유무 를 확인하고 완전 절제가 되었음을 확인하였다. 면역조직화 학적 검사에서 신경계통 표지자인 S-100 단백에 대해서 양성

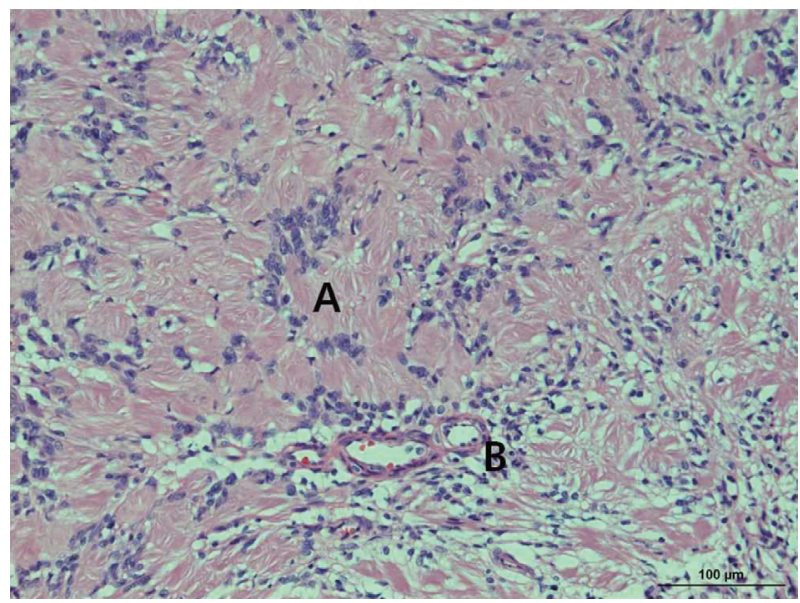

Fig. 3. Schwannoma with two main patterns: Antoni type A (hypercellular area, A) and Antoni type B (loosely arranged cells, B) $(\times 200)$.

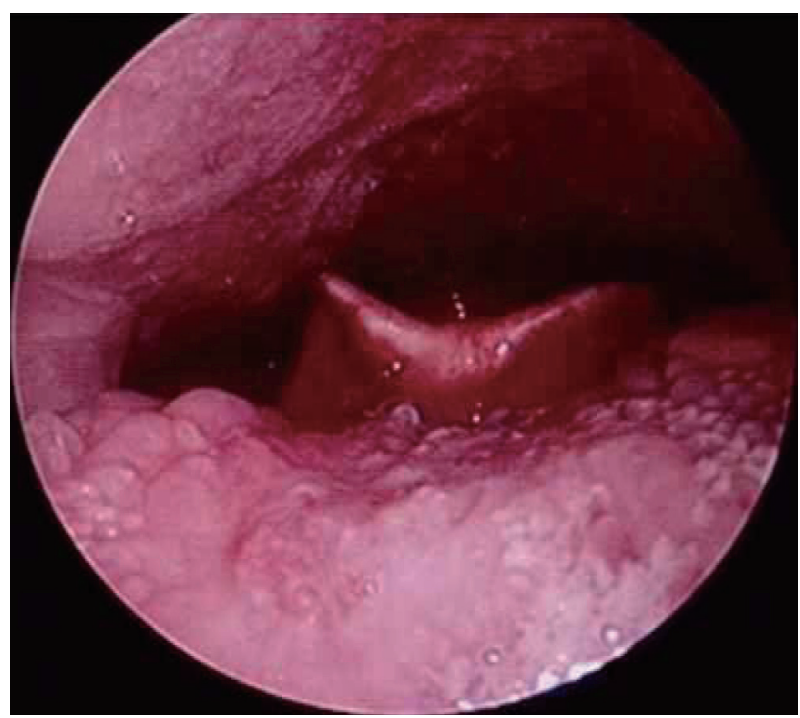

Fig. 4. Postoperative photo shows that the mass was completely removed.

반응을 보였으며, 조직 슬라이드상 가장 외측의 정상 혀 상피 세포층 아래에 방추상 세포들이 밀집된 구역인 Antoni A 부 분과 비교적 세포의 배열이 넓고 느슨한 Antoni B 부분을 관 찰할 수 있었다(Fig. 3). 이에 설 기저부의 신경초종으로 최종 진단되었다.

환자는 술 후 1 일째 경구식이를 시작하였고 불편감은 호소 하지 않았으며 발음, 미각, 혀의 움직임에도 이상 소견이 없었 다. 이후 부작용 및 후유증 없이 퇴원하였고 수술 후 2주일째 외래에서 관찰한 수술 부위는 이상소견 없이 깨끗하게 관찰 되었다(Fig. 4). 현재 환자는 본원 이비인후과 외래를 통해 경 과관찰 중이며, 갑상선 기능항진증으로 내분비내과에서 치료 중이다. 


\section{고 찰}

신경초종은 이비인후과 영역에서는 청신경에 발생하는 경 우가 가장 많이 보고되고 있으며, 구강 내에서 발생하는 경 우는 드물다. 구강내 신경초종은 혀에서 가장 흔하게 발생하 며 협부 점막, 경구개, 구강저, 구순에도 발생하지만 설 기저 부에 생기는 경우는 드물다. ${ }^{1,5}$ 어느 연령에서나 발생할 수 있 고 주로 20,30 대에서 흔한 것으로 보고되어 있다. ${ }^{6,7)}$ 신경초 종은 성장이 느리고 전이를 하지 않기 때문에 대부분 종물 에 의한 이물감 외에 다른 증상을 보이지 않는 것이 보통이다. 그러나 구강내 발생한 경우 그 크기에 따라서 이물감, 언어장 애, 연하장애, 수면무호흡증 등이 나타날 수 있다. ${ }^{8)}$ 그리고 신경초종이 발생한 기원이 되는 신경의 기능이상을 보일 수 있지만 대략 10 50\%에서만 직접적인 연관증상을 보인다. ${ }^{9,10}$ 본 증례에서 환자는 인후두 불편감 및 이물감 외에는 다른 특별한 증상을 호소하지 않았고 혀의 움직임의 이상이나 미 각장애 등 구강 내의 신경기능 이상을 의심할 만한 소견은 없 었다. 따라서 기원신경을 추측하기는 힘들지만 종물의 해부 학적 위치상 설신경 또는 그 분지에서 유래된 것으로 보인다.

수술 전 평가한 갑상선 기능검사에서 free T4가 $1.88 \mathrm{ng} / \mathrm{dL}$ 로 경미한 갑상선 기능항진증이 있었으며, 신체 진찰상 종물 이 설 기저부 정중선의 설맹공(foramen cecum)에 존재하고 있어 이소성 갑상선의 가장 흔한 형태인 설 갑상선으로 오인 하였다. 설 갑상선 환자의 대략 70 75\%에서 정상 갑상선이 부재하다고 알려져 있지만, 본 환자는 CT scan상 정상 갑상 선이 존재하는 것이 확인되었다. 이에 수술 전에 설 갑상선 혹 은 덧갑상선(accessory thyroid gland)에 대한 추가검사를 시행하기보다 수술적 절제를 시행하는 치료 계획을 수립하 였다. 구강내 돌출된 종물로 세침흡입세포검사(fine needle aspiration)는 시행이 불가능했고 국소 마취하에 조직검사도 고려해 보았으나 구역반사가 너무 심했고, 출혈 가능성이 높 은 상태로 흡인(aspiration)의 위험을 생각하여 전신 마취하 에 수술을 시행하여 안전하게 제거하는 동시에 동결절편 검 사를 계획하였다. 본 증례와 달리 갑상선 기능에 심한 이상 이 있으며 정상 갑상선을 확인하지 못하는 경우라면 확진을 위해 Tc-99m, I-131 또는 I-123을 이용한 신티그래피(scintigraphy) 및 갑상선 스캔을 시행하는 것이 유용할 수 있겠 다. 증례에서 점막하부에 무통증으로 피막이 존재하는 것은 신경초종을 의심할 수 있는 소견이었으며, 설배부 뒤쪽으로 $3 \sim 8 \mathrm{~cm}$ 크기의 혈관이 풍부해 보이는 소견은 설갑상선을 의 심할 수 있는 특징이었다. 설 기저부에 생기는 종괴의 소견은 설갑상선 외에도 갑상설낭, 유피낭, 악성 종양 등을 추가적으 로 생각할 수 있으며, 이와 같은 다양한 질환들을 감별하기 위
해서는 환자의 병력과 검진소견을 종합적으로 검토해야 한다.

신경초종에 있어서 본 증례와 같이 기원하는 신경의 기능 이상이나 마비가 없는 경우 술 전에 그것을 진단하기는 어렵다. 따라서 술 전에 magnetic resonance imaging(MRI), 초음파 등의 영상학적 검사 및 세침흡인검사 또는 일부 조직을 채취 하는 세포병리검사를 실시하여 병변에 대한 최대한의 자료 를 확보하는 것이 치료의 방침을 결정하는 데 있어 중요할 것 이라 생각된다. 신경초종은 CT 상에서 경계가 명확하고 균질 하게 조영 증강이 되는 종물로 나타난다. 하지만 CT는 주변 의 치아 및 인공물로 인해 관찰의 제한이 있을 수 있다. 반면 $\mathrm{MRI}$ 는 CT와 비교했을 때 종괴의 조영증강이 잘되고 해상도 가 좋으며, 인공물질의 제한이 없기 때문에 영상학적으로 신경 초종을 진단하는 데 있어 가장 좋은 검사라고 할 수 있다. ${ }^{11,12)}$

병리학적으로 신경초종은 종양을 둘러싸고 있는 섬유 피막 및 설 상피세포와 균일하고 길어진 모양의 핵과 방추 세포로 구성되어 있다. 크게 Antoni A와 Antoni B의 두 가지 조직 배 열이 서로 혼재되어 관찰된다. 방추상 세포들로 구성되고 세 포들이 조밀하게 밀집된 구역인 Antoni $\mathrm{A}$ 구역과 상대적으 로 세포의 밀집이 적고 배열이 불규칙하고 엉성한 Antoni B 구역을 관찰할 수 있다. 특히 Antoni A 구역에서 핵이 결여된 밀집된 부위인 Verocay body를 관찰할 수 있다. ${ }^{13)}$

신경초종의 치료는 수술적인 절제가 원칙이다. ${ }^{13)}$ 주로 신경 초종은 피막에 둘러싸여 있어 피막을 따라 종물을 벗겨내는 피막내 절제술(intracapsular enucleation)이 주가 된다. 하지 만 8 10\%에서 악성화가 가능하다고 되어 있기 때문에 피막 이 없는 경우에는 정상조직을 포함한 안전연을 두고 절제를 해야 한다. ${ }^{14)}$ 본 증례와 같이 설 기저부의 표면에 위치한 종물 의 경우 경구개법으로 절제가 가능하지만 혀의 깊은 부위에 발 생한 경우 다른 접근법을 고려해야 한다. 수술 시 적절한 노 출이 어렵다면 신경 손상으로 인한 발음장애, 연하장애, 흡 인 등의 합병증이 동반될 수 있기 때문이다. 경구개법(transoral approach) 외에 경설골법(transhyoid approach), 경설골상법 (suprahyoid approach), 경부접근법(transcervical approach), 하악골절개법(mandibulotomy) 등 다양한 접근법이 가능하 며 종물의 위치에 따라 적절한 접근법이 필요하다. ${ }^{13,15)}$

신경초종은 발생 빈도가 적어 구강내 종양의 감별진단의 우선순위에서 제외되는 경우가 많아 진단 및 치료가 늦어질 수 있다. 설 기저부에 발생한 신경초종을 진단함에 있어 신경 의 이상을 의심할 소견은 없이 갑상선 기능항진이 동반되어 설 갑상선으로 오인한 감별진단에 어려움을 겪은 증례를 경 험하여 문헌 고찰과 함께 보고하는 바이다. 


\section{REFERENCES}

1) Enzinger FM, Weiss SW. Soft tissue tumors. 3rd ed. St Louis: MosbyYear Book;1995. p.821-88.

2) Katz AD, Passy V, Kaplan L. Neurogenous neoplasms of major nerves of face and neck. Arch Surg 1971;103(1):51-6.

3) Pfeifle R, Baur DA, Paulino A, Helman J. Schwannoma of the tongue: report of 2 cases. J Oral Maxillofac Surg 2001;59(7):802-4.

4) Martins MD, Anunciato de Jesus L, Fernandes KP, Bussadori SK, Taghloubi SA, Martins MA. Intra-oral schwannoma: case report and literature review. Indian J Dent Res 2009;20(1):121-5.

5) Krolls SO, McGinnis JP Jr, Quon D. Multinodular versus plexiform neurilemoma of the hard palate. Report of a case. Oral Surg Oral Med Oral Pathol 1994;77(2):154-7.

6) Takeda Y. Neurilemmoma in the maxillary alveolar bone: report of a case. Br J Oral Maxillofac Surg 1991;29(3):208-10.

7) Kang GC, Soo KC, Lim DT. Extracranial non-vestibular head and neck schwannomas: a ten-year experience. Ann Acad Med Singapore 2007;36(4):233-8.

8) George NA, Wagh M, Balagopal PG, Gupta S, Sukumaran R, Sebastian P. Schwannoma base tongue: case report and review of literature. Gulf J Oncolog 2014;1(16):94-100.
9) Hibbert J. Scott-Brown's Otolaryngology, 6Ed: Volume 5: Laryngology and Head \& Neck Surgery. 6th ed. Oxford: Taylor \& Francis;1997.

10) Dreher A, Gutmann R, Grevers G. [Extracranial schwannoma of the ENT region. Review of the literature with a case report of benign schwannoma of the base of the tongue]. HNO 1997;45(6):468-71.

11) Spandow O, Fagerlund M, Bergmark L, Boquist L. Clinical and histopathological features of a large parapharyngeal neurilemmoma located at the base of the tongue. ORL J Otorhinolaryngol Relat Spec 1999;61(1):25-30.

12) Grainger RG. Grainger and Allison's Diagnostic Radiology: A Textbook of Medical Imaging. 4th ed. Orlando: Churchill Livingstone; 2001. p.2339.

13) de Bree R, Westerveld GJ, Smeele LE. Submandibular approach for excision of a large schwannoma in the base of the tongue. Eur Arch Otorhinolaryngol 2000;257(5):283-6.

14) Chang SC, Schi YM. Neurilemmoma of the vagus nerve. A case report and brief literature review. Laryngoscope 1984;94(7):946-9.

15) Cohen M, Wang MB. Schwannoma of the tongue: two case reports and review of the literature. Eur Arch Otorhinolaryngol 2009;266(11): 1823-9. 